\title{
Genetic Relationships among Breeds of Goldfish Based on Isozyme Variations
}

\author{
Minoru Ikeda, Takayuki Kawakami, and Yoshihisa Fujio \\ Laboratory of Fish Genetics and Breeding Science, Faculty of Agriculture, Tohoku University, \\ Sendai 981-8555, Japan
}

(Received April 30, 1998)

\begin{abstract}
Genetic variability and differentiation in six breeds including three varieties of goldfish (Wakin, Ryukin, Comet, Oranda-shishigashira, Aka-, Kuro-, Sansyoku-demekin, and Ranchu) were examined by enzyme electrophoresis. Within a breed, average heterozygosity $\left(H_{\mathrm{e}}\right)$, estimated from allele frequencies at 26 loci, ranged from 0.046 to 0.100 with a mean of 0.072 . Nei's genetic distance $(D)$ between breeds was ranging from 0.0015 to 0.0239 with a mean of 0.0116 , indicating that the level of differentiation among breeds falls into the range of local races. The dendrogram constructed from the genetic distance showed that the Wakin, Ryukin, and Comet were clustered together, the three varieties of Demekin and Oranda-shishigashira formed another cluster, and the Ranchu was only distantly related to the other breeds.
\end{abstract}

Key words: goldfish, breed, genetic relationship, isozyme

The goldfish Carassius auratus auratus is one of the most famous domesticated fish. Complete domestication of this fish was archieved in China by the middle of the 12 th century. Subsequently, in that country, many variants with respect to pigmentation and body structure were found, and many breeds were created by breeders. The created breeds of the goldfish had been introduced into Japan sometime around the 1500 's. Also in Japan, new breeds and varieties were created based on the breeds which were imported, predominantly, in the 18th and 19th centuries.

Based on the crossbreeding experiments, Matsui ${ }^{1)}$ suggested that the creation of breeds of the goldfish was apparently based on visible mutations such as fundamentally changing pigmentation, the structure of fins and eyes, the structure of the integument, the shape of the body, and other characteristics. Subsequently, Matsui ${ }^{1-3)}$ constructed the genealogy of goldfish breeds or varieties. However, the relationships among breeds proposed by Matsui ${ }^{1-3)}$ have not yet been inspected by using modern molecular genetic analysis.

The goldfish and the other cyprinid species (carp and crucian carp) are thought to have evolved from a tetraploid origin where extensive gene duplication occurred.4) This complicates a genetic interpretation of electrophoretic patterns and causes difficulties for quantifing the genetic variability within a breed or the differentiation among breeds in goldfish. Recently, we have revealed the genetic controls of several isozymes in goldfish showing complicated patterns on a gel, by the examination of tissue specifity, heat stability of the isozymes, and crossbreeding experiments. ${ }^{5-7)}$

The aim of the present study is to quantify the genetic variation and the degree of genetic differentiation in six breeds of goldfish by using enzyme electrophoresis including the 16 loci scored recently, ${ }^{5-7)}$ and to discuss the genetic relationships among breeds examined and compare them with the genealogy proposed by Matsui. ${ }^{1-3)}$

\section{Materials and Methods}

Five different breeds (Wakin, Comet, Ryukin, Orandashishigashira, and Ranchu) and three varieties within a Demekin (Pop-eyed) breed (Kuro-demekin, Sanshoku-demekin, and Aka-demekin) of goldfish, with 13-70 specimens respectively, were obtained from a breeder in Yatomi Town, Aichi Prefecture in 1993. The collecting data are shown in Table 1. The morphological and historical features of the breeds or varieties examined in this study are as described in Matsui ${ }^{1-3)}$ and Zhang Zhong-ge. ${ }^{8)}$ According to the information from the breeder, the broodstock of each breed or variety is maitain in the isolated pond. The size of each stock is about 500 individuals in the Wakin, 200-300 in the Comet, Ryukin, Oranda-shishigashira, three varieties of the Demekin, and less than 100 in the Ranchu. Sex ratio in all stocks is approximately 1.1 (male): 1 (female). The eggs are laid on the nests prepared in each pond on April, and hacthed progenies are reared for one or two years when they reach a size large enough to permit commercial sale. A part of the progenies is remained for the next propagation.

The samples of breeds and varieties were kept in our

Table 1. Collecting data for breeds of goldfish examined in this study

\begin{tabular}{lcc}
\hline Breed & Sample size & $\begin{array}{c}\text { Standard length (cm) } \\
\text { (mean } \pm \text { SD) }\end{array}$ \\
\hline Wakin & 70 & $11.1 \pm 1.4$ \\
Ryukin & 44 & $9.8 \pm 0.5$ \\
Comet & 44 & $12.2 \pm 1.5$ \\
Kuro-demekin & 30 & $6.2 \pm 0.9$ \\
Sansyoku-demekin & 30 & $6.1 \pm 1.2$ \\
Aka-demekin & 13 & $6.3 \pm 0.3$ \\
Oranda-shishigashira & 28 & $10.9 \pm 0.5$ \\
Ranchu & 30 & $6.8 \pm 0.4$ \\
\hline
\end{tabular}


Table 2. Enzymes, tissues, and locus examined in this study on goldfish

\begin{tabular}{|c|c|c|c|}
\hline Enzyme (abbreviation) & E.C. number & Tíssue & Locus \\
\hline Alchol dehydrogenase (ADH) & 1.1 .1 .1 & Muscle & $A D H^{*}$ \\
\hline Aspartate aminotransferase (AAT) & 2.6.1.1 & Liver & $A A T-1^{*}, A A T-2^{*}, A A T-3^{*}$ \\
\hline Fumarase $(\mathrm{FH})$ & 4.2.1.2 & Muscle & $F H-1^{*}, F H-2^{*}$ \\
\hline Glucosephosphate isomerase (GPI) & 5.3 .1 .9 & Muscle & $G P I-I^{*}, G P I-3^{*}$ \\
\hline Lactate dehydrogenase (LDH) & 1.1 .1 .27 & $\begin{array}{l}\text { Liver } \\
\text { Muscle } \\
\text { Brain } \\
\text { Liver }\end{array}$ & $\begin{array}{l}G P I-2^{*} \\
L D H \cdot A^{*}, L D H-B I^{*}, L D H-B 2^{*} \\
L D H-E^{*} \\
L D H-F^{*}\end{array}$ \\
\hline Malate dehydrogenase (MDH) & 1.1 .1 .37 & $\begin{array}{l}\text { Muscle } \\
\text { Liver }\end{array}$ & $\begin{array}{l}M D H-A 1^{*}, M D H-A 2^{*}, M D H-C 1^{*}, M D H-C 2^{*} \\
M D H-B 1^{*}, M D H-B 2^{*}\end{array}$ \\
\hline Mannnose-6-phosphate isomerase (MPI) & 5.3 .1 .8 & Muscle & $M P I^{*}$ \\
\hline Phosphoglucose dehydrogenase (PGDH) & 1.1 .1 .44 & Liver & $P G D H-I^{*}, P G D H-2^{*}$ \\
\hline Phosphoglucomutase (PGM) & 2.7 .5 .1 & Muscle & $P G M-1^{*}, P G M-2^{*}$ \\
\hline Superoxide dismutase (SOD) & 1.15.1.1 & Liver & $S O D^{*}$ \\
\hline
\end{tabular}

Table 3. Allele frequencies at eight isozyme loci in six breeds and three varieties of goldfish

\begin{tabular}{|c|c|c|c|c|c|c|c|c|c|}
\hline \multirow[b]{2}{*}{ Locus } & \multirow[b]{2}{*}{ Allele } & \multirow[b]{2}{*}{$\begin{array}{c}\text { Wakin } \\
(70)\end{array}$} & \multirow[b]{2}{*}{$\begin{array}{c}\text { Comet } \\
\text { (44) }\end{array}$} & \multirow[b]{2}{*}{$\begin{array}{c}\text { Ryukin } \\
\text { (44) }\end{array}$} & \multicolumn{3}{|c|}{ Demekin } & \multirow{2}{*}{$\begin{array}{c}\text { Oranda- } \\
\text { shishigashira } \\
\text { (28) }\end{array}$} & \multirow[b]{2}{*}{$\begin{array}{c}\text { Ranchu } \\
\text { (30) }\end{array}$} \\
\hline & & & & & $\begin{array}{c}\text { Kuro } \\
(30)\end{array}$ & $\begin{array}{l}\text { Sansyoku } \\
(30)\end{array}$ & $\begin{array}{l}\text { Aka } \\
(13)\end{array}$ & & \\
\hline \multirow[t]{3}{*}{$G P I-I^{*}$} & ${ }^{*} a$ & 0.007 & 0.057 & 0 & 0 & 0 & 0 & 0 & 0 \\
\hline & ${ }^{*} b$ & 0.672 & 0.545 & 0.614 & 0.767 & 0.900 & 0.923 & 0.714 & 0.783 \\
\hline & ${ }^{*} c$ & 0.321 & 0.398 & 0.386 & 0.233 & 0.100 & 0.077 & 0.286 & 0.217 \\
\hline \multirow{2}{*}{$G P I-2^{*}$} & ${ }^{*} a$ & 0.750 & 0.966 & 1.000 & 0.967 & 0.950 & 0.923 & 0.893 & 0.983 \\
\hline & ${ }^{*} b$ & 0.250 & 0.034 & 0 & 0.033 & 0.050 & 0.077 & 0.107 & 0.017 \\
\hline \multirow[t]{3}{*}{$G P I-3^{*}$} & ${ }^{*} a$ & 0 & 0 & 0 & 0 & 0 & 0.077 & 0.125 & 0 \\
\hline & ${ }^{*} b$ & 0.993 & 0.989 & 0.932 & 1.000 & 1.000 & 0.923 & 0.875 & 1.000 \\
\hline & ${ }^{*} c$ & 0.007 & 0.011 & 0.068 & 0 & 0 & 0 & 0 & 0 \\
\hline \multirow[t]{2}{*}{$L d h-B I^{*}$} & ${ }^{*} a$ & 0.557 & 0.420 & 0.477 & 0.133 & 0.233 & 0.231 & 0.125 & 0.200 \\
\hline & ${ }^{*} b$ & 0.443 & 0.580 & 0.523 & 0.867 & 0.767 & 0.769 & 0.875 & 0.800 \\
\hline \multirow[t]{3}{*}{$M P I^{*}$} & ${ }^{*} a$ & 0.286 & 0.405 & 0.442 & 0.383 & 0.450 & 0.654 & 0.611 & 0.017 \\
\hline & ${ }^{*} b$ & 0.714 & 0.595 & 0.511 & 0.617 & 0.550 & 0.346 & 0.389 & 0.983 \\
\hline & ${ }^{*} c$ & 0 & 0 & 0.047 & 0 & 0 & 0 & 0 & 0 \\
\hline \multirow[t]{2}{*}{$P G D H-I^{*}$} & ${ }^{*} a$ & 0.157 & 0.227 & 0.045 & 0.100 & 0.150 & 0 & 0.268 & 0.633 \\
\hline & ${ }^{*} b$ & 0.843 & 0.773 & 0.955 & 0.900 & 0.850 & 1.000 & 0.732 & 0.367 \\
\hline \multirow[t]{2}{*}{$P G D H-2^{*}$} & ${ }^{*} a$ & 0.986 & 1.000 & 1.000 & 1.000 & 1.000 & 1.000 & 0.857 & 1.000 \\
\hline & ${ }^{*} b$ & 0.014 & 0 & 0 & 0 & 0 & 0 & 0.143 & 0 \\
\hline \multirow[t]{2}{*}{$P G M-1^{*}$} & ${ }^{*} a$ & 0.813 & 0.841 & 0.798 & 0.783 & 0.833 & 0.885 & 0.714 & 1.000 \\
\hline & ${ }^{*} b$ & 0.187 & 0.159 & 0.202 & 0.217 & 0.167 & 0.115 & 0.286 & 0 \\
\hline \multirow[t]{2}{*}{$P G M-2^{*}$} & $* a$ & 0.993 & 1.000 & 1.000 & 1.000 & 1.000 & 1.000 & 1.000 & 1.000 \\
\hline & ${ }^{*} b$ & 0.007 & 0 & 0 & 0 & 0 & 0 & 0 & 0 \\
\hline $\begin{array}{l}P \\
H_{e}\end{array}$ & & $\begin{array}{l}0.231 \\
0.100\end{array}$ & $\begin{array}{l}0.192 \\
0.085\end{array}$ & $\begin{array}{l}0.192 \\
0.079\end{array}$ & $\begin{array}{l}0.192 \\
0.063\end{array}$ & $\begin{array}{l}0.231 \\
0.063\end{array}$ & $\begin{array}{l}0.231 \\
0.055\end{array}$ & $\begin{array}{l}0.308 \\
0.088\end{array}$ & $\begin{array}{l}0.116 \\
0.046\end{array}$ \\
\hline
\end{tabular}

Monomorphic loci: $A A T-1^{*}, A A T-2^{*}, A A T-3^{*}, A D H^{*}, F H-1^{*}, F H-2^{*}, L D H-B 2^{*}, L D H-A^{*}, L D H-E^{*}, L D H-F^{*}, M D H-A I^{*}, M D H-A 2^{*}, M D H-B 1^{*}, M D H-B 2^{*}$, $M D H-C I^{*}, M D H-C 2^{*}$, and $S O D^{*}$.

Sample size indicated in parentheses.

laboratory pond or stored at $-50^{\circ} \mathrm{C}$. The brain, heart, skeletal muscle, and liver of each specimen were used for electrophoresis. Horizontal starch gel electrophoresis was carried out as described by Fujio. ${ }^{9)}$ TC-7 (tris-citric acid, $\mathrm{pH} 7.0)^{9)}$ was adopted for the buffer system. The enzymes, loci, and tissues examined are shown in Table 2. The nomenclature of loci encoding GPI, LDH, MDH, and PGDH were followed as from the previous studies..$^{5-7}$ Genotypes were scored from phenotypes on electropherograms. Alleles at each locus were designated by letters in alphabetical order, starting with the allele encoding the most anodally migrating isozymes.

The proportion of polymorphic loci ( $P: 95 \%$ criterion) and average heterozygosity $\left(H_{\mathrm{e}}\right)$, as measures of genetic variability, were calculated. A coefficient of gene diversity
$\left(G_{\mathrm{ST}}\right)^{10)}$ was calculated from the mean of heterozygosities within breeds $\left(H_{\mathrm{S}}\right)$ and the average heterozygosity in the total breed or variety $\left(H_{\mathrm{T}}\right)$. To examine the genetic relationships among breeds or varieties, a dendrogram was constructed by using the UPGMA ${ }^{(1)}$ based on the Nei's genetic distance $(D) .{ }^{12)}$

\section{Results}

Out of 26 loci encoding ten enzymes examined, 17 loci $\left(A A T-1^{*}, A A T-2^{*}, A A T-3^{*}, A D H^{*}, F H-I^{*}, F H-2^{*}\right.$, $L D H-A^{*}, L D H-B 1^{*}, L D H-E^{*}, L D H-F^{*}, M D H-A 1^{*}$, $M D H-A 2^{*}, M D H-B 1^{*}, M D H-B 2^{*}, M D H-C 1^{*}, M D H-$ $C 2^{*}$, and $S O D^{*}$ ) were monomorphic in all the breeds. The remaining nine loci showed variants and the two loci (GPI- 
$I^{*}$ and $L D H-B 1^{*}$ ) were polymorphic in all breeds (Table 3 ). At these loci, the observed frequencies of genotypes were in good agreement with the expected values under HardyWeinberg equilibrium in each breed and variety $\left(\chi^{2}\right.$-test, $p>0.05$ ).

The proportion of polymorphic loci $(P)$ was from 0.116 to 0.301 with an average of 0.212 . The average heterozygosity $\left(H_{c}\right)$ was 0.046 to 0.100 with a mean of 0.072 . The breed of Wakin showed a tendency of higher genetic variability than the other breeds. While the Ranchu showed the lowest values of the two parameters for genetic variability in all breeds.

The coefficient of gene diversity $\left(G_{\mathrm{ST}}\right)$ among all breeds or varieties within a breed are shown in Table 4 . The value of $G_{\mathrm{ST}}$ in all breeds including the three varieties of the Demekin breed was 0.122 . The value in all breeds when the three varieties of Demekin were pooled was 0.126 . These results indicate that approximately $12 \%$ of the total gene diversity in the goldfish is found among breeds. Within the Demekin breed, however, the $G_{\mathrm{ST}}$ value was 0.048 which indicated that the gene diversity within a breed is smaller than that among breeds.

Nei's genetic distance $(D)$ between all breeds including the three varieties was calculated from allele frequencies at the 26 loci (Table 5). The $D$ values varied from 0.0015 (between Kuro- and Sansyoku-demekin) to 0.0350 (between Aka-demekin and Ranchu) with a mean of 0.0116 . The $D$ values between Ranchu and the other breeds (ranged from 0.0179 to 0.0350 with a mean of 0.0239 ) were higher than those of any other pairs of breeds. The $D$ values between three varieties within the Demekin breed ranged from 0.0015 to 0.0056 with a mean of 0.0034 .

A dendrogram was constructed using UPGMA from the matrix of Nei's genetic distance (Table 5) as shown in Fig. 1. The Wakin, Comet, and Ryukin formed a cluster, and the three varieties of Demekin and Oranda-shishigashira formed another cluster. These clusters connected together at the distance of 0.0097 and joined the Ranchu at 0.0239 which indicated that the Ranchu was only distantly related

Table 4. The coefficient of gene diversity $\left(G_{\mathrm{ST}}\right)$ in breeds of goldfish

\begin{tabular}{|c|c|c|c|}
\hline & $H_{\mathrm{T}}$ & $H_{\mathrm{T}}$ & $G_{\mathrm{ST}}$ \\
\hline Six breeds* & 0.082 & 0.072 & 0.122 \\
\hline Six breeds ${ }^{* *}$ & 0.087 & 0.076 & 0.126 \\
\hline Within Demekin breed & 0.063 & 0.060 & 0.048 \\
\hline
\end{tabular}

* including three varieties of the Demekin.

** three varieties of the Demekin were pooled.

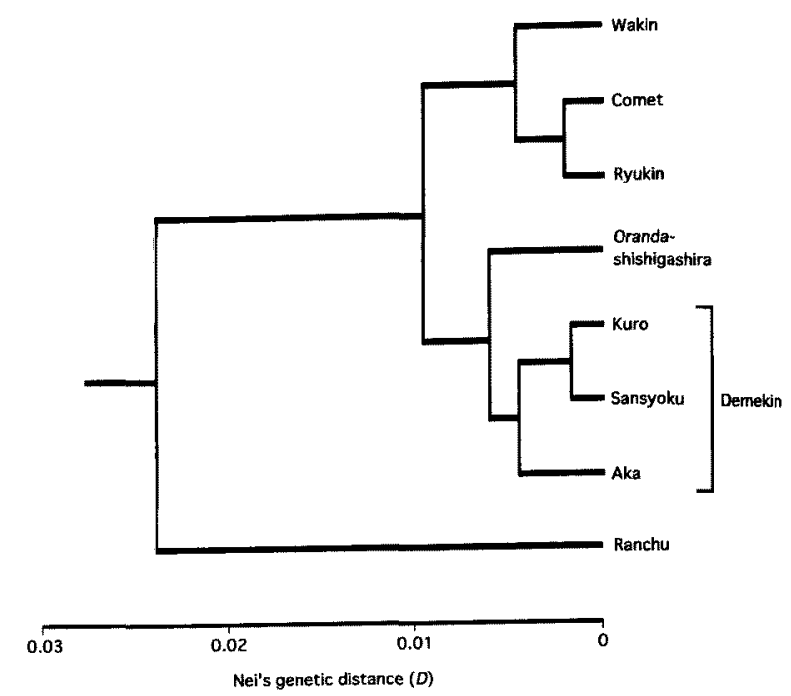

Fig. 1. Genetic relationships among breeds of goldfish in this study, The dendrogram was constructed by the UPGMA from Nei's genetic distance $(D)$ based on the allele frequencies at 26 loci.

to the other breeds.

\section{Discussion}

The mean genetic variability in all goldfish breeds examined in this study was 0.212 in the proportion of polymorphic loci $(P)$ and 0.072 in average heterozygosity $\left(H_{\mathrm{e}}\right)$. For the genetic variability in fish species, Fujio and Kato ${ }^{13)}$ reported that estimates for all fish (41 species) were $0.194 \pm 0.023$ in the proportion of polymorphic loci $(P)$ and $0.059 \pm 0.007$ in average heterozygosity $\left(H_{e}\right)$. In comparison with their report, the genetic variability in goldfish is relatively high. However, the genetic variability of the Wakin breed tended to be higher than the other breeds, and the Ranchu breed showed the lowest values among all the breeds. This difference might be caused by the different levels of artficial selection in the production of these breeds.

Regarding the level of genetic differentiation, $\mathrm{Ne}^{{ }^{14)}}$ found that the genetic distance $(D)$ was approximately 1.0 among congeneric species, 0.1 among subspecies, and 0.01 among local races. According to these rough criteria, the mean of the genetic distance $(\vec{D}=0.0116)$ between breeds in goldfish falls into the range of the local races. Within the Demekin breed, the $G_{\mathrm{ST}}$ value among three varieties (Aka-, Kuro-, and Sansyoku-demekin) was lower than that among the breeds and the three varieties clustered on

Table 5. Nei's genetic distance $(D)$ between breeds of goldfish calculated from allele frequencies at 26 isozyme loci

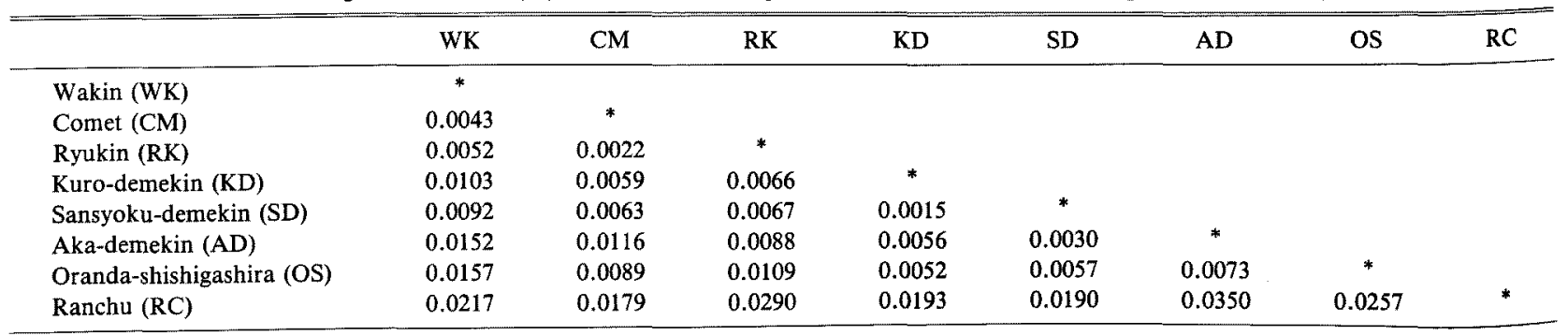


the dendrogram constructed from the genetic distance. This suggests that the three varieties within the Demekin breed have been derived from a single lineage.

Matsui ${ }^{1-3)}$ proposed the genealogy of goldfish breeds from the results of the crossbreeding experiments between different breeds. According to Matsui, ${ }^{1-3)}$ the development of all the breeds and varieties examined in this study were based on the mutants for the pigmentation and the structure of the fin, eyes, and body shape found in the original stocks. The process of establishment of goldfish breeds examined in this study was as follows: the Wakin was originated from red colored crucian carp (Hibuna); the Ryukin was produced from the Wakin; the Comet was derived from the Ryukin introduced to the United States from Japan; the Oranda- shishigashira was produced from the Ryukin; within the Demekin breed, Aka-demekin which has protuberant eyes originated at the beginning of the production of the Ryukin from the Wakin, and Kuro- and Sansyoku-demekin with mutant pigmentations originated from Aka-demekin; the Ranchu established in Japan was produced from the Maruko breed which was produced earlier than all the other breeds, except for the Wakin. The dendrogram constructed from genetic distance $(D)$ between breeds examined in this study showed that the Wakin, Ryukin, and Comet were clustered together, the three varieties within the Demekin and Orandashishigashira formed another cluster, and the Ranchu was only distantly related to the other breeds. Except for the Oranda-shishigashira derived from the Ryukin, which was related to the Demekin breed, the dendrogram seems to support Matsui's proposal. ${ }^{1-3)}$ This result, however, must be careful considered, because the genetic distance and relationships among breeds based on allele frequencies at isozymic loci might be influenced by the fluctuation of effective population size in propagation of each breed. Thus, the exact geneology among breeds of goldfish must be determined by further studies.
Acknowledgments This work was supported by a Grant-in-Aid for Scientific Research from the Ministry of Education, Science, Sports, and Culture of Japan (08406014).

\section{References}

1) Y. Matsui: Genetical studies on gold-fish of Japan. 1. On the varieties of gold-fish and variations in their external characteristics. 2. On the Mendelian inheritance of the telescope eyes of gold-fish. 3 . On the inheritance of the scale transparency of gold-fish. 4. On the inheritance of caudal and anal fins of gold-fish. J. Imper. Fish. Inst., 30, 1-90 (1934).

2) Y. Matsui: Gold-fish, in "Exhibits in International Genetics Symposium" Tokyo, Kyoto, 1956, pp. 97-105.

3) Y. Matsui: Kingyo, Color Books, vol. 34, Hoikusya, Osaka, 1963, p. 153 (in Japanese).

4) S. Ohno, J. Muramoto, L. Christian, and N. B. Atkin: Diploidtetraploid relationship among old-world members of the fish family Cyprinidae. Chromosoma, 23, 1-9 (1967).

5) T. Takase, A. Kijima, and Y. Fujio: Genetic polymorphism and isozyme patterns of 6-phosphogluconate dehydrogenase in goldfish and crucian carp. Tohoku J. Agr. Res., 47, 67-75 (1997).

6) T. Takase, A. Kijima, and Y. Fujio: Detection of heat stability variants in GPI isozymes of goldfish and crucian carp. Fisheries Sci., 64, 31-34 (1998).

7) M. Ikeda, S. Yamamoto, and Y. Fujio: Genetic controls of MDH and LDH isozymes in the goldfish. Tohoku J. Agr. Res., 48, 43-52.

8) Zhang Zhong-ge: Goldfish, in "Evolution of Domesticated Animals" (ed. by I. L. Marson), Longman, New York, 1984, pp. 381-385.

9) Y. Fujio: Study on Genetic Characteristic of Fish and Shellish in Isozyme Analysis, Report of the Special Experimental Research, Ministry of Agriculture and Fisheries of Japan, Tokyo, 1984, p. 53 (in Japanese).

10) M. Nei: Analysis of gene diversity in subdivided populations. Proc. Natl. Acad. Sci. U.S.A., 70, 3321-3323 (1973).

11) P. H. A. Sneath and R. R. Sokal: Numerical Taxonomy, Freeman, San Francisco, 1973, p. 573.

12) M. Nei: Genetic distance between populations. Amer. Natur., 106, 283-292 (1972).

13) Y. Fujio and $Y$. Kato: Genetic variation in fish populations. Nippon Suisan Gakkaishi, 45, 1169-1178 (1979).

14) M. Nei: Molecular Population Genetics and Evolution, North-Holland, Amsterdam, 1975, p. 288. 